\title{
Effects of geological structures on groundwater flow and quality in hardrock regions of northern Tirunelveli district, southern India
}

\author{
M Senthilkumar $^{1, *}$, R Arumugam ${ }^{1}$, D Gnanasundar $^{1}$, D S C Thambi $^{2}$ and E Sampath Kumar ${ }^{1}$ \\ ${ }^{1}$ Central Ground Water Board, SECR, MoWR, Govt. of India, Chennai 600 090, India. \\ ${ }^{2}$ Central Ground Water Board, Bhujal Bhavan, Faridabad 121 001, India. \\ ${ }^{*}$ Corresponding author.e-mail: msent50@yahoo.com
}

Geological and structural influences on groundwater flow and quality were evaluated in the present study in the hardrock regions of Tirunelveli District, southern India. Groundwater is a major source of freshwater in this region to cater to the requirements of domestic and agricultural activity, as there are no surface water resources. Geologically, the area is characterized by charnockites and garnetiferous biotite gneiss. Groundwater in this region is found to occur in the weathered portion under unconfined condition and in fractured/fissured portions under unconfined to semi-confined condition. Existence of deep-seated fractures are minimal. Lineaments/dykes play a major role in the occurrence and movement of groundwater in the region. Lineaments/dykes of the study area can be broadly divided into two types: north-south and west-east oriented structures. Analysis and field observations revealed that the northsouth dykes act as a barrier of groundwater while the west-east oriented structures behave as a carrier of groundwater. Both quality and quantity of groundwater is different on the upstream and downstream sides of the dyke. Hence, it is conclusive that the west-east oriented dykes in this region are highly potential and act as a conduit for groundwater movement from recharge areas to the discharge area.

\section{Introduction}

Groundwater is the major source of freshwater that caters to the domestic water demand arising due to escalating population and modern agricultural practices in many developing countries. Groundwater is generated through a large number of borewells, tube wells and dug wells, which are spread in the agricultural fields, residential areas, and industrial areas. The heavy withdrawal of groundwater has resulted in lowering of groundwater levels, which in turn has caused deterioration in groundwater quality. The continuing groundwater exploitation has not only resulted in lowering of groundwater levels but also increased the wide variation in the zone of fluctuation. The withdrawal has led to several quality-related problems. The geological structures play a major role in the groundwater flow and quality-related problems. The geologic structures like dykes, lineaments, and fractures act as both carriers as well as barriers for groundwater flow. There have been many studies/ technical reports showing the role of dykes in controlling the groundwater flow in an area (Nilsen et al. 2003; Al-Taj 2008; Perrin et al. 2011). Several researchers have used spatial distribution of geology, geomorphology, landuse, drainage, and lineaments to identify groundwater potential zones (Srinivasa and Jugran 2003; Nag 2005; Mondal et al. 2007; Vasanthavigar et al. 2011). Many researchers have also reported that dykes that behave as barriers have quality-related problems in

Keywords. Dykes; lineaments; barrier; groundwater flow; southern India. 
the upstream side (Srinivasa and Jugran 2003; Nag 2005; Mondal et al. 2007). One such study was carried out in the northern part of Tirunelveli district, south India where groundwater flow and quality is mainly controlled by the geological structures. Few hydrogeological studies have been carried out by researchers of Central Ground Water Board from time to time to appraise the groundwater scenario of the area (Vardaraj 1984; Kunhambu 1990; Sampath Kumar 1994; Senthilkumar 2010). The present study was carried out to investigate the effects of geological structures on groundwater movement and quality.

\section{Methodology}

Detailed hydrogeological survey was carried out during May 2010. In order to understand the hydrogeological setting of the region, the available geological maps and existing reports were studied. As there were some data gaps, an intensive geological investigation was carried out in the study area, to study the nature of the rock, topographical expressions, intensity and depth of weathering, and demarcation of lithological contacts on a larger scale than the presently available maps. The thickness and intensity of weathering were studied from borehole lithologs, information from river cuttings, and well section/walls. Thickness of the cement casing rings/walls in the dug wells was very useful for determining the thickness of the weathered formation/overburden. Further, villagewise well inventory study was carried out and 183 wells were inventoried. Groundwater level, electrical conductivity and GPS locations were recorded during the inventory field survey. Spatial analysis of the inventoried wells was carried out and point anomaly values were discarded and 120 wells were identified as representative wells for the study (figure 1). Groundwater level and EC values were monitored from these 120 representative wells during pre-monsoon period (May 2010), further during September 2010 and during post-monsoon period January 2011.

\section{Study area}

The study area covers $3203 \mathrm{~km}^{2}$ and lies in the northern part of the Tirunelveli district, southern India. The area is bounded by north latitude of $08^{\circ} 34^{\prime} 35^{\prime \prime}$ and $09^{\circ} 19^{\prime} 20^{\prime \prime}$ and east longitude of $77^{\circ} 08^{\prime} 15^{\prime \prime}$ and $77^{\circ} 48^{\prime} 30^{\prime \prime}$ forming parts of the Survey

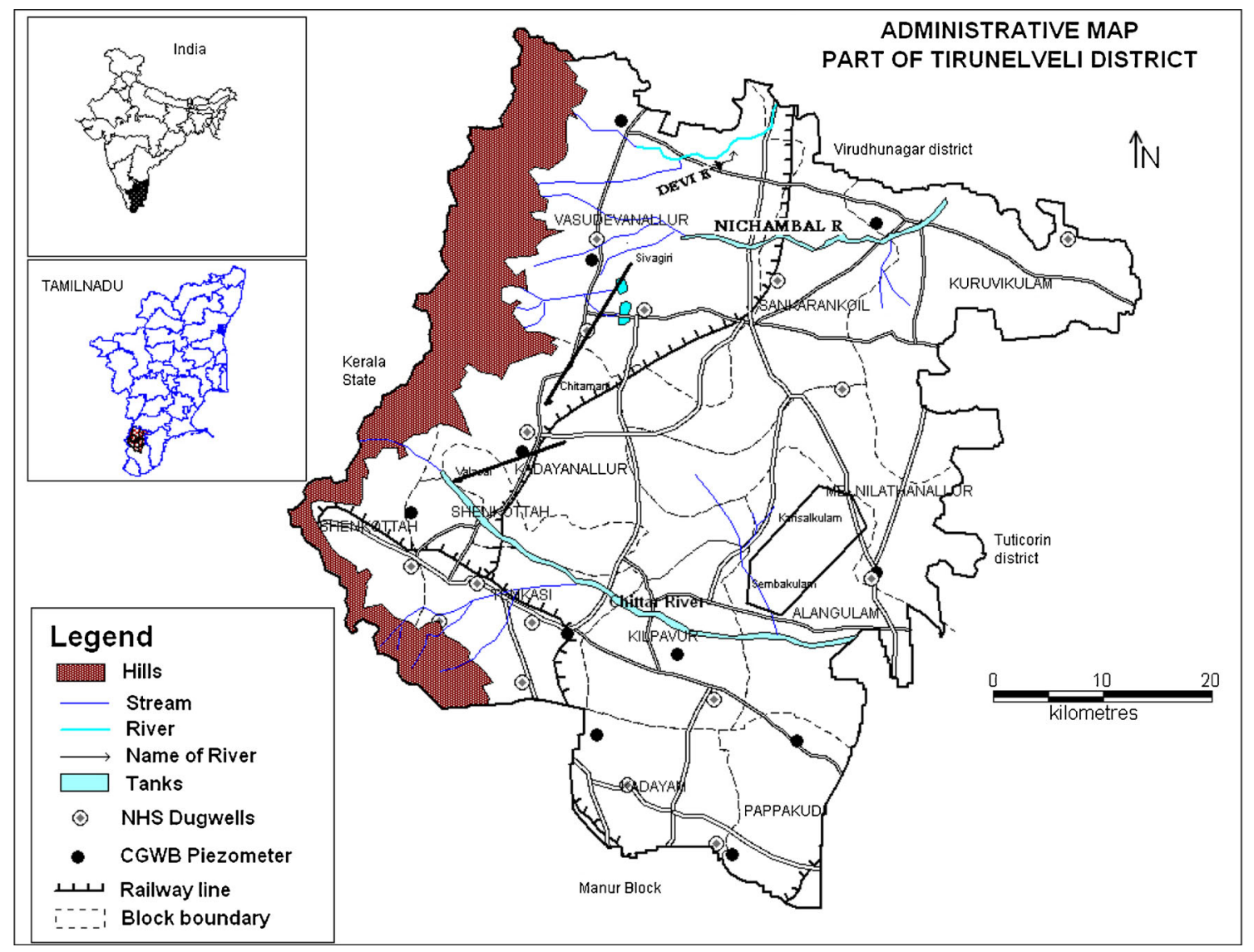

Figure 1. Administrative set-up of the study area. 
of India toposheets of $58 \mathrm{H} / 1,5,9,58 \mathrm{G} / 7,8$, 11,15 , and 16 . The study area is bounded in the north by the Virudunagar district, in the east by Tuticorin district and in the south by Manur and Tirunelveli blocks of Tirunelveli district. In the western side, it is bound by the Western Ghats/Kerala State. Survey was carried out over an area of $3203 \mathrm{~km}^{2}$ comprising of 6 talukas and 11 blocks namely Sankarankoil, Tenkasi, Alangulam, Kadayam, Vasudevanallur, Melaneelithanallur, Kurivikulam, Pappakudi, Shencottai, Kadayanallur, and Keelapavour blocks (figure 1). The study area experiences an average annual rainfall of $1100 \mathrm{~mm}$ (average of 30 years 1971-2000). This is mainly contributed by the NE monsoon $(58 \%)$, SW monsoon about $28 \%$, and remaining by summer rains. The major part of the study area is covered by deep red soil and it occupies about $56 \%$ of the study area. The second major soil type is the black cotton soil, it is found in the eastern part of the study area and it covers about $32 \%$ of the total area. Another soil type found in the study area is the red sandy soil. River Chittar is the major river within the study area. There are few cascades and water falls in the study area, of which the Koutralum and five falls are prominent.

\subsection{Hydrogeological settings}

The crystalline rocks of Achaean age consisting of charnockites, gneisses and basic and acidic intrusive underlie the study area. Generalised geological map of the study area is given in figure 2 . Based on field survey, it is observed that crystalline rocks of Achaean age cover a major portion of the study area. Groundwater in the study area is found to occur in the weathered portion, fissured, and fractured zones in these crystalline rocks. The occurrence and movement of groundwater is controlled by various factors like physiography, climate, geology and structural features like lineament and dykes. Groundwater is found to occur under unconfined conditions in the weathered portion and unconfined to semi-confined nature in the fissured and fractured crystalline rocks. Potential zones have been identified in the colluvial deposits of Sivagiri-Chintamani belt (figure 1) and it extends up to Puliyangudi area (Senthilkumar 2010). Kadayanallur-Valasai area is potential due to the presence of $\mathrm{W}-\mathrm{E}$ oriented lineament. Wells in these areas have the yield of about 5-6 lps for 810 hrs with a drawdown of about 1-2 m. Potential pockets are also seen in Karisalkulam-Sembakulam region on the eastern side of the study area

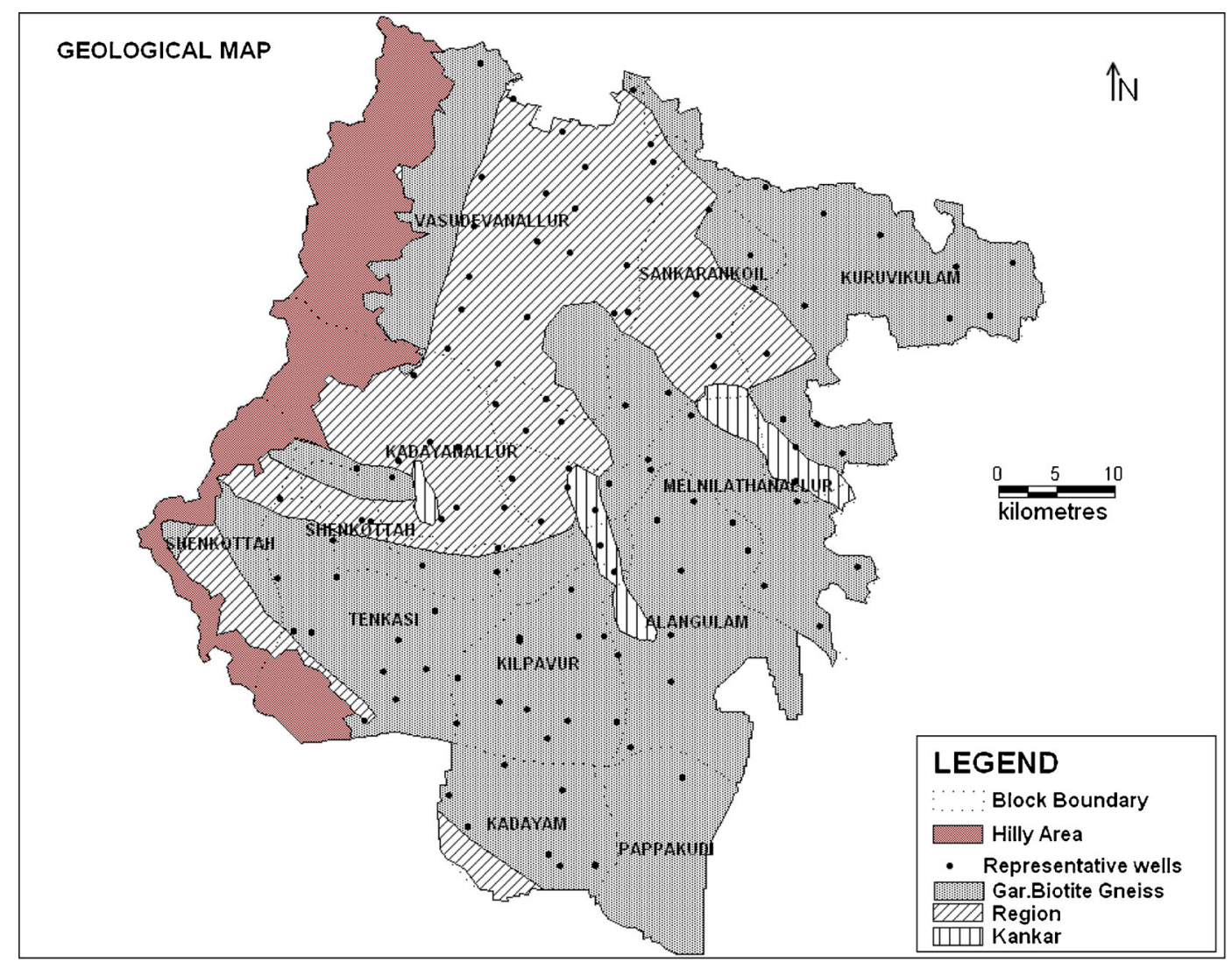

Figure 2. Geological map with key well locations. 
(figure 1). Falling in the quadrant of Survey of India toposheet 58G12-C2-C3 covering an area of $22-25 \mathrm{~km}^{2}$, the area has high groundwater potential. Depth of the wells in this belt ranges from 14 to $21 \mathrm{~m}$ below ground level (bgl) and groundwater levels range from 11 to $15 \mathrm{~m} \mathrm{bgl}$ (premonsoon). Wells in these regions have the yield of about 5-6 lps for 8-10 hrs with a drawdown of about 1-2 m. Among the crystalline rocks, gneisses have appreciable thickness of weathered mantle and have numerous open joint planes. Charnockites in the area, on the other hand, have generally low water-yielding capacity due to their resistance to weathering and widely spaced tight joints, except in contact zones and structurally weak zones. The prominent lineaments trend is north north-east-south south-west, north-west-southeast directions. Yield of the phreatic aquifer comprising charnockites is moderate but the quality is potable, while the phreatic aquifer comprising of gneisses with tectonic disturbance have good yield but poor quality. Exploratory drilling activity carried out by Central Ground Water Board has revealed the absence of deep seated fractures in Kurivikulam, Melaneelithanallur and Sankarankoil blocks. Potential fractures have been encountered up to depth of $62 \mathrm{~m} \mathrm{bgl}$ with discharge of 1.2-3.3 lps in parts of Sivagiri-Chintamani belt. Regions between the Chintamani and Sivagiri are of high potential. Depth of weathering in this area is about 09-15 mbgl and pre-monsoon groundwater level ranges between 11 and $15 \mathrm{~m}$ bgl. Groundwater in this region can be further developed by lowering the groundwater level by $5 \mathrm{~m}$. As the region is located near the foothills, immediate recharge shall take place after the monsoon (induced recharge). Downstream of Ramanadi and Gatana reservoirs, groundwater levels are very shallow and almost prone to water logging conditions. Groundwater of these regions can be pumped to other water scarce areas. The quality of groundwater is highly fresh. EC values range from 25 to $300 \mu \mathrm{S} / \mathrm{cm}$. There are springs present in the study area. These are natural discharges of groundwater. During the survey, a spring was monitored near the Gatana Reservior. The EC value was $35 \mu \mathrm{S} / \mathrm{cm}$ with a discharge of $<1$ lps (Senthilkumar 2010).

\subsection{Well and aquifer parameters}

Large diameter pumping tests were carried out in 12 representative wells in the study area during the pre- and post-monsoon periods. Specific capacity, transmissivity, and specific yield were calculated based on the methodology of Ramsahoy and Delang. Aquifer parameters computed during the study period are tabulated in table 1 .

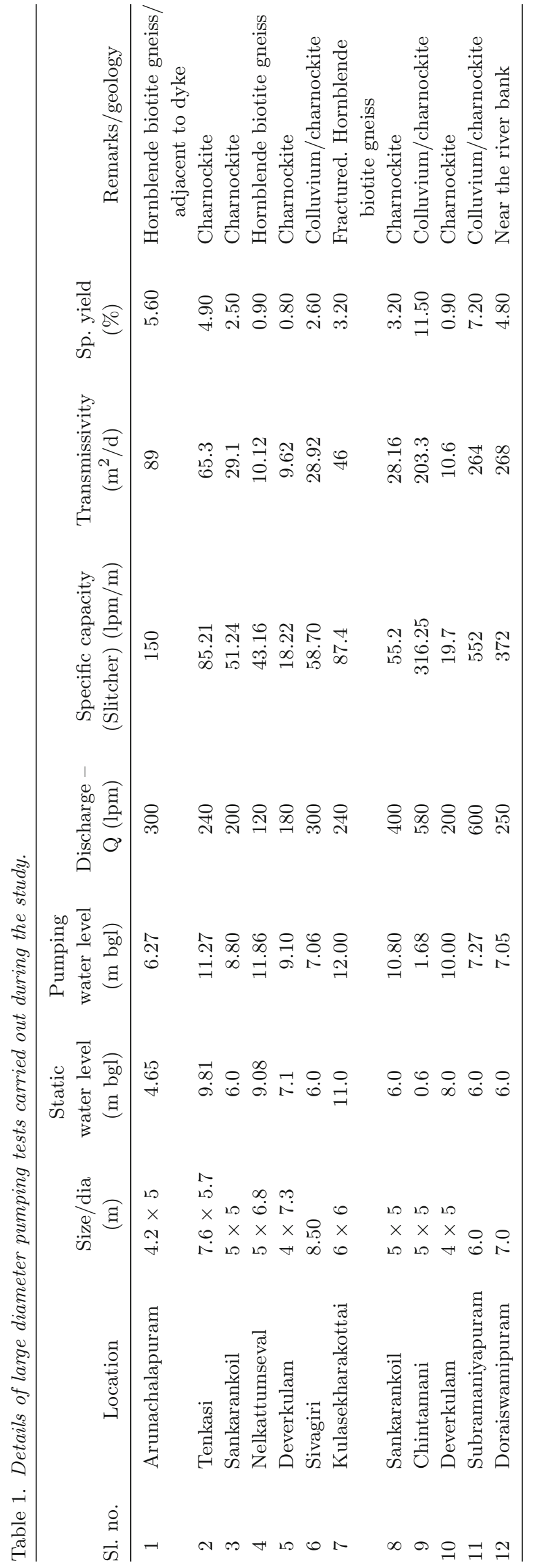


Table 2(a). Range of groundwater level during May, September 2010 and January 2011.

\begin{tabular}{|c|c|c|c|c|c|c|}
\hline \multirow{2}{*}{$\begin{array}{l}\text { DTW range } \\
(\mathrm{m} \mathrm{bgl})\end{array}$} & \multicolumn{2}{|c|}{$\begin{array}{l}\text { No. of key wells falling in the } \\
\text { range during May } 2010\end{array}$} & \multicolumn{2}{|c|}{$\begin{array}{l}\text { No. of key wells falling in the } \\
\text { range during September } 2010\end{array}$} & \multicolumn{2}{|c|}{$\begin{array}{c}\text { No. of key wells falling in the } \\
\text { range during January } 2011\end{array}$} \\
\hline & No. of wells & $\%$ & No. of wells & $\%$ & No. of wells & $\%$ \\
\hline $0-3$ & 07 & 05 & Nil & 00 & 2 & 01 \\
\hline $3-6$ & 18 & 15 & 03 & 02 & 18 & 15 \\
\hline $6-9$ & 27 & 22.5 & 19 & 15 & 33 & 27.5 \\
\hline $9-12$ & 29 & 24.1 & 34 & 28.3 & 30 & 25 \\
\hline $12-15$ & 31 & 25.8 & 45 & 37.5 & 29 & 24.1 \\
\hline $15-18$ & 10 & 08 & 19 & 15 & 08 & 06 \\
\hline
\end{tabular}

Table 2(b). Relationship between groundwater level and electrical conductivity.

\begin{tabular}{|c|c|c|c|}
\hline \multirow[b]{2}{*}{ Month of measurement } & \multicolumn{2}{|c|}{ Area occupied $\left(\mathrm{km}^{2}\right)$} & \multirow{2}{*}{$\begin{array}{c}\text { Average ground water } \\
\text { level }(\mathrm{m} \mathrm{bgl})\end{array}$} \\
\hline & $\overline{\mathrm{EC}}$ values $<1500 \mu \mathrm{S} / \mathrm{cm}$ & EC values $>1500 \mu \mathrm{S} / \mathrm{cm}$ & \\
\hline May 2010 & 2025.42 & 1174.58 & 10.07 \\
\hline September 2010 & 2336.86 & 863.14 & 12.70 \\
\hline February 2011 & 2032.37 & 1167.63 & 9.35 \\
\hline
\end{tabular}

Table 2(c). Range of chemical constituents in the groundwater of the study area.

\begin{tabular}{lllr}
\hline Parameters & \multicolumn{1}{c}{ Min } & \multicolumn{1}{c}{ Max } & Mean \\
\hline $\mathrm{pH}$ & 7.5 & 8.2 & 7.9804762 \\
$\mathrm{EC}(\mu \mathrm{S} / \mathrm{cm})$ & 426 & 4380 & 1547.6667 \\
$\mathrm{TH}(\mathrm{mg} / \mathrm{l})$ & 140 & 1720 & 468.92857 \\
$\mathrm{Ca}(\mathrm{mg} / \mathrm{l})$ & 4 & 416 & 80.285714 \\
$\mathrm{Mg}(\mathrm{mg} / \mathrm{l})$ & 9.7216 & 204.1536 & 60.962533 \\
$\mathrm{Na}(\mathrm{mg} / \mathrm{l})$ & 18.4 & 506 & 150.08048 \\
$\mathrm{~K}(\mathrm{mg} / \mathrm{l})$ & 0.782 & 31.28 & 10.221857 \\
$\mathrm{CO}(\mathrm{mg} / \mathrm{l})$ & 0 & 0 & 0 \\
$\mathrm{HCO}(\mathrm{mg} / \mathrm{l})$ & 73.224 & 616.302 & 178.9920 \\
$\mathrm{Cl}(\mathrm{mg} / \mathrm{l})$ & 24.815 & 1155.67 & 313.39488 \\
$\mathrm{SO}{ }_{4}(\mathrm{mg} / \mathrm{l})$ & 6.0851613 & 710.4 & 138.66359 \\
$\mathrm{NO}_{3}(\mathrm{mg} / \mathrm{l})$ & 10.743871 & 367.77097 & 62.210161 \\
$\mathrm{~F}(\mathrm{mg} / \mathrm{l})$ & 0.3427308 & 1.907131 & 1.1071626 \\
\hline
\end{tabular}

A perusal of table 1 clearly indicates the abrupt variation in the aquifer parameters from place to place. This is mainly because of the heterogeneity resulting from the degree of weathering and structures influencing the groundwater flow. Specific capacity ranges from 19.7 to $552 \mathrm{lpm} / \mathrm{m}$. Transmissivity ranges between 9.62 and $268 \mathrm{~m}^{2} /$ day. Wells located in the colluvial deposit has very high transmissivity values. Area adjacent to the ChintamaniSivagiri belt has very high transmissivity values ranging from 28 to $264 \mathrm{~m}^{2} /$ day. Specific yield values ranged between 0.90 and $11.5 \%$. Aquifer characteristic computed based on the pumping test and air test carried out in the wells drilled by CGWB in the study area is described below. The transmissivity values ranged between 0.8 and $33.80 \mathrm{~m}^{2} /$ day.

\subsection{Depth to water level}

The depth of occurrence of groundwater in the phreatic aquifer of the study area depicted from the 120 key wells during the pre-monsoon period of May 2010 ranges from 2.25 to $22.10 \mathrm{~m}$ bgl. Shallowest groundwater level is observed in Papakudi village and deepest groundwater level of 22.10 $\mathrm{m}$ bgl is observed in Ariyanayarkuppam village. During September 2010, the groundwater level ranged from 5.50 to $23.00 \mathrm{~m} \mathrm{bgl}$. The shallowest groundwater level of $5.50 \mathrm{~m}$ bgl was observed in Papakudi village and deepest groundwater level of 23.00 $\mathrm{m}$ bgl is observed in Ariyanayarkuppam village. Postmonsoon period, the groundwater level ranged from 1.60 to $16.70 \mathrm{~m} \mathrm{bgl}$. The shallowest groundwater level is observed in Kalurinkulam and deepest groundwater level is observed in Periyaswamipuram village. Range of the groundwater level measured during these periods is given in table 2(a).

\subsection{Spatial distribution of groundwater level}

Spatial distribution of the depth to groundwater level map for the period September 2010 and February 2011 is given in figure 3. Groundwater level was monitored during May 2010. A study of the May 2010 data reveals that deep water levels greater than $12 \mathrm{~m} \mathrm{bgl}$ are observed in the central, northern and north-western sides. About $34 \%$ of the area fall under deeper water levels ( $>12 \mathrm{~m} \mathrm{bgl})$. Shallow water levels are observed in the southern parts, which are also a reflection of the dam, canal areas, and reservoirs, etc. These regions occupy about $20 \%$ of the total area. About $5 \%$ of the area is prone to water logging having groundwater level $<3 \mathrm{~m}$ bgl. Average groundwater level 

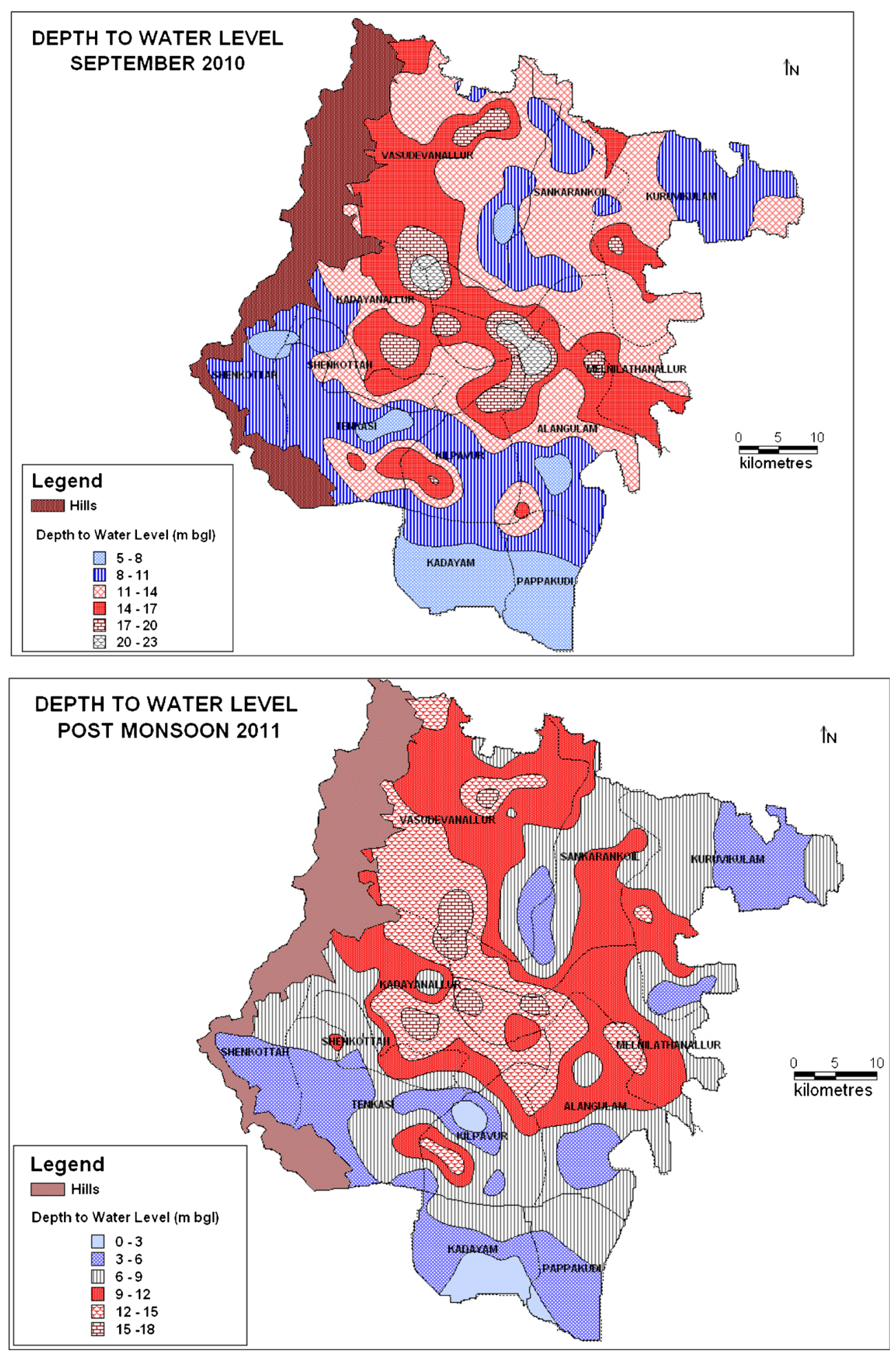

Figure 3. Depth to groundwater level during pre- and post-monsoon period.

of the 120 keywells is $10.07 \mathrm{~m}$. A perusal of the September 2010 (figure 3) depth to water level map reveals that the depth to groundwater level has lowered further down. An increase in the percentage of deeper groundwater levels is observed. The depth to groundwater levels greater than $12 \mathrm{~m} \mathrm{bgl}$ is observed in $53 \%$ of the total wells.
These areas are observed in the northern and central portions of the study area. Shallow groundwater levels and areas prone for water logging during the May 2010 measurements have declined gradually. Shallowest groundwater level recorded is 5.5 $\mathrm{m}$ bgl. Average groundwater level during September 2010 of the 120 keywells is $12.70 \mathrm{~m}$. Spatial 
distribution of the post-monsoon (January 2011) depth to groundwater level map (figure 3) reveals that the deeper groundwater levels are observed in the central portion of the study area. Only $30 \%$ of the areas have groundwater levels deeper than $12 \mathrm{~m}$ bgl. A major part of the study area has groundwater level in the range of $6-12 \mathrm{~m} \mathrm{bgl}$ $(53 \%)$. Shallow groundwater levels are observed in the southern, south-western, and north-eastern portions of the study area. About $16 \%$ of the wells have groundwater level $<6 \mathrm{~m}$ bgl. Average groundwater level during post-monsoon period is $9.35 \mathrm{~m} \mathrm{bgl}$.

\subsection{Groundwater table}

In order to ascertain and know the pattern of groundwater flow in the phreatic aquifer of the surveyed area, groundwater table map was prepared from the key wells. Reduced level values of these key wells were obtained from Survey of India toposheets. Groundwater table map of the study area is given in figure 4. A study of the groundwater table map reveals that the groundwater flows from the western side towards the south-eastern side. The gradient decreases from the west towards the south-eastern side. Steep gradients are observed in the central portion of the study area. Groundwater table of the study area ranges from $>190$ to $50 \mathrm{~m}$ amsl.

\subsection{Lineament/dyke analysis}

The study area is occupied by crystalline rocks, which have been subjected to polyphase of tectonic activity resulting in high degree of metamorphism, migmatisation, and mutli-generation of faulting and folding. The dykes are generally considered as impermeable and hence they are likely to function as barriers for groundwater flow, but in few cases, they function as carriers. In order to study the role of dykes on groundwater conditions, dyke/lineament mapping was carried out. The major lineaments in the study area have been demarcated from the satellite imagery and are presented in figure 5. Northwest-southeast (II), northsouth (V), west-east (I) and northeast-southwest (III) oriented structures are prominent in the study area. The study of satellite imagery revealed the presence of a number of minor and major lineaments and trending mostly in NNE-SSW and NW-SE directions.

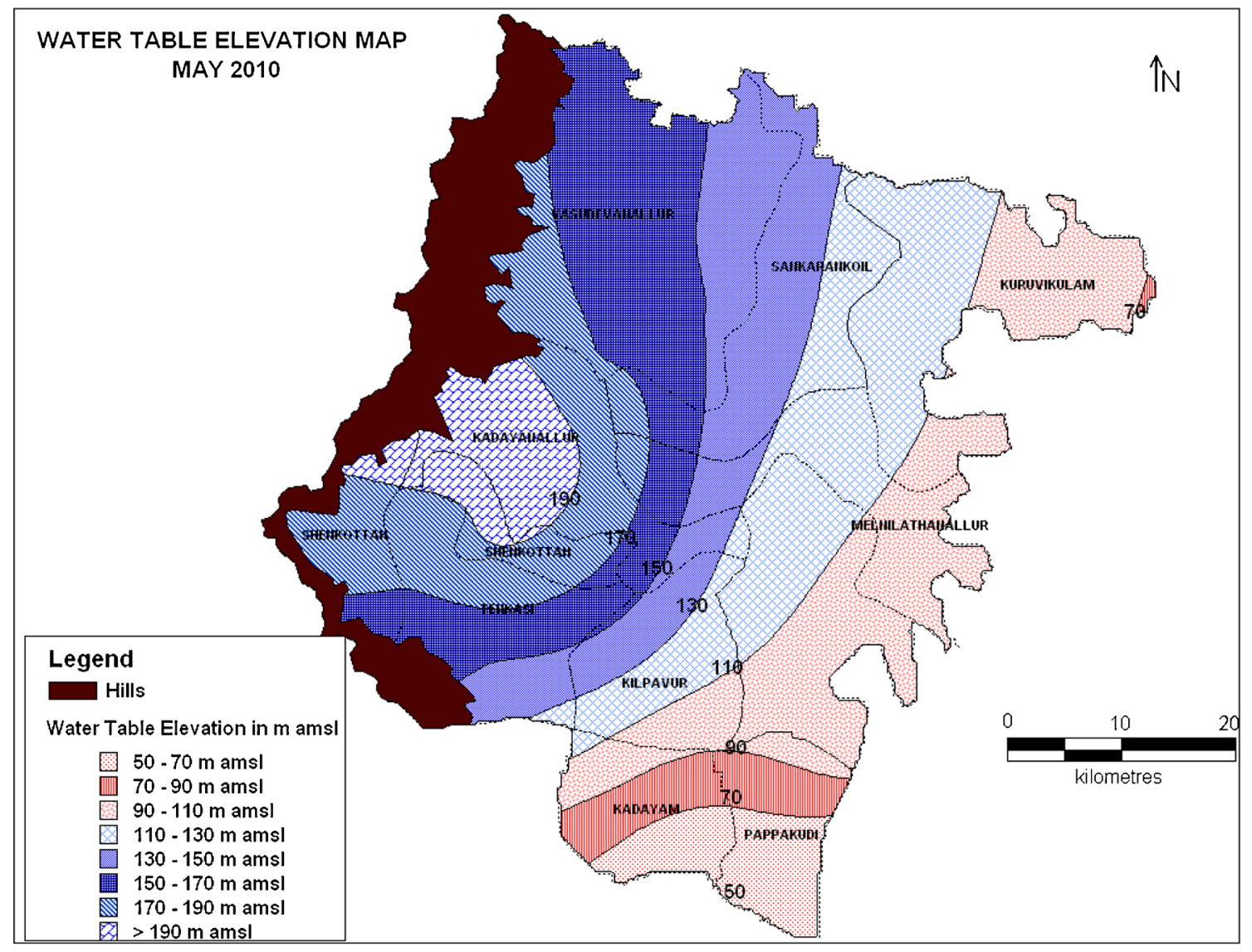

Figure 4. Groundwater table map showing flow direction. 


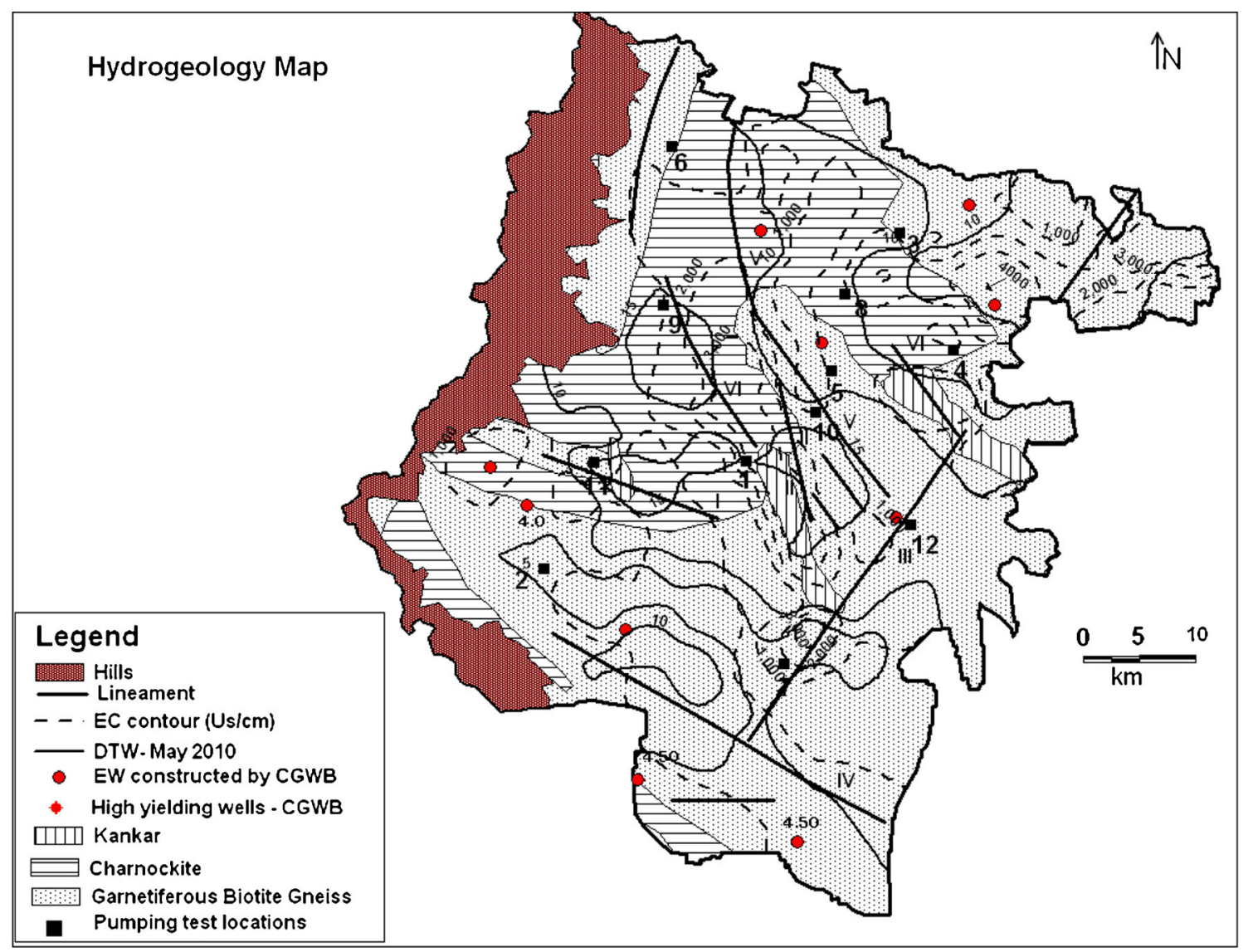

Figure 5. Hydrogeology and structural map of the study area.

\subsection{Hydrogeochemistry}

To understand the hydrogeochemistry and chemical parameters controlling the groundwater in the study area, 120 representative wells were selected and 42 groundwater samples collected during premonsoon period (May 2011). The electrical conductivity values range from 426 to $4380 \mu \mathrm{S} / \mathrm{cm}$ with an average value of $1548 \mu \mathrm{S} / \mathrm{cm}$ (table $2 \mathrm{~b}$ ). Of the 42 samples, 16 groundwater samples have EC values higher than permissible limit of $1500 \mu \mathrm{S} / \mathrm{cm}$. Detailed analysis of electrical conductivity in the groundwater of the study area is discussed in detail in the below paragraph.

The $\mathrm{pH}$ of groundwater samples vary from 7.5 to 8.2 with a mean value of $7.98 \mathrm{pH}$ of the groundwater samples of the study area is neutral. The order of dominance of the cations of the study area is $\mathrm{Na}>\mathrm{Ca}>\mathrm{Mg}>\mathrm{K}$ and of the anions is $\mathrm{Cl}<\mathrm{HCO}_{3}<\mathrm{CO}_{3}<\mathrm{SO}_{4}$. Sodium is the major and dominant cation. Sodium concentration of the study area varies from 10 to $138 \mathrm{mg} / \mathrm{l}$. Calcium ranges from 04 to $416 \mathrm{mg} / \mathrm{l}$ with an average of $80 \mathrm{mg} / \mathrm{l}$. Four groundwater samples of the $42 \mathrm{sam}-$ ples have calcium values more than the permissible limit (ISI 1983). Magnesium ranges from 10 to
$204 \mathrm{mg} / \mathrm{l}$ with an average of $61 \mathrm{mg} / \mathrm{l}$. The potassium values range from 1 to $31 \mathrm{mg} / \mathrm{l}$ with an average value of $10 \mathrm{mg} / \mathrm{l}$. Chloride is the dominant anion, which ranges from 23 to $591 \mathrm{mg} / \mathrm{l}$ and the chloride content is in the range of $21-1156 \mathrm{mg} / 1$ with an average of $313 \mathrm{mg} / \mathrm{l}$. Ten groundwater samples out of the 42 samples have chloride values more than permissible limit (500 mg/l) (ISI 1983). Chloride values more than $500 \mathrm{mg} / \mathrm{l}$ is observed in the central and north-eastern portions of the study area. Central and north-eastern portions of the study area have high chloride concentration. Sulphate concentration ranges from 6 to $710 \mathrm{mg} / \mathrm{l}$ with an average of $138 \mathrm{mg} / \mathrm{l}$. Bicarbonate concentration of the study area ranges from 73 to 616 $\mathrm{mg} / \mathrm{l}$ with an average $179 \mathrm{mg} / \mathrm{l}$. Nine out of the 42 groundwater samples have sulphate values more than the permissible limit (ISI 1983). Fluoride concentration in the study area ranges $0.34-1.91 \mathrm{mg} / \mathrm{l}$ with an average $1.106 \mathrm{mg} / \mathrm{l}$. Fluoride concentration more than $1 \mathrm{mg} / \mathrm{l}$ was found in the northern portion of the study area. Eight out of the 42 groundwater samples have fluoride concentration more than the permissible limit (ISI 1983). Nitrate concentration in the study area ranges $10.7-367.8 \mathrm{mg} / \mathrm{l}$ with an average of $62.2 \mathrm{mg} / \mathrm{l}$. The 
major portion of the study area has nitrate concentration within the permissible limit (ISI 1983). Sixteen groundwater samples of the 42 samples have nitrate concentration more than $45 \mathrm{mg} / \mathrm{l}$. north-eastern portion of the study area has high nitrate concentration. During this period of MaySeptember 2010, the EC values have decreased with increase in groundwater level. Table 2(c) clearly indicates the increase in the area occupied by potable water (EC values less than 1500 $\mu \mathrm{S} / \mathrm{cm}$ ). The average groundwater level in the 120 key wells during May 2010 is $10.07 \mathrm{~m} \mathrm{bgl}$ while in September, the average groundwater level lowers to $12.7 \mathrm{~m}$ bgl. The groundwater level during the month of May 2010 ranges within the weathered zone, i.e., $10.07 \mathrm{~m}$ (average GWL), while in September 2010, the groundwater level declines and reaches the massive formations with minimal fractures. Time series analysis comparing the groundwater level and EC values also shows the pattern observed in the study area. EC values decrease with increase in groundwater level from
May to September 2010 and EC values increase with decrease in groundwater level. Hence, shallower the groundwater level, higher is the $\mathrm{EC}$ value in the study area. Groundwater flow direction in the study area is from the north-western/western side towards the south-eastern/eastern direction. The presence of dykes oriented in the $\mathrm{N} 20^{\circ} \mathrm{E}$ and north-south direction hinder the groundwater to flow towards the eastern side. These dykes here act as barrier stopping the groundwater to flow further. This causes stagnation effect near the barrier, which also helps in increase of residence time of groundwater in a particular place near these structures aiding to release/exchange of ions from and between the formation and water (rock-water interaction). To understand and identify the hydrogeochemical processes that are taking place in the study area, the Gibb's (1970) plot (figure 6a) was used to identify the mechanisms that control the groundwater chemistry of the study area. This plot shows the distribution of the data points mostly in the rock dominance zone and a few

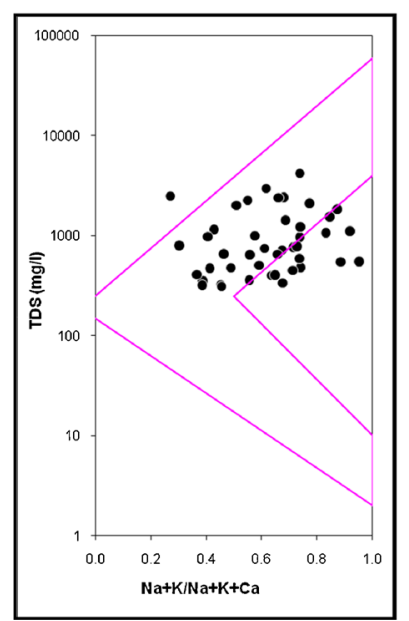

(a)

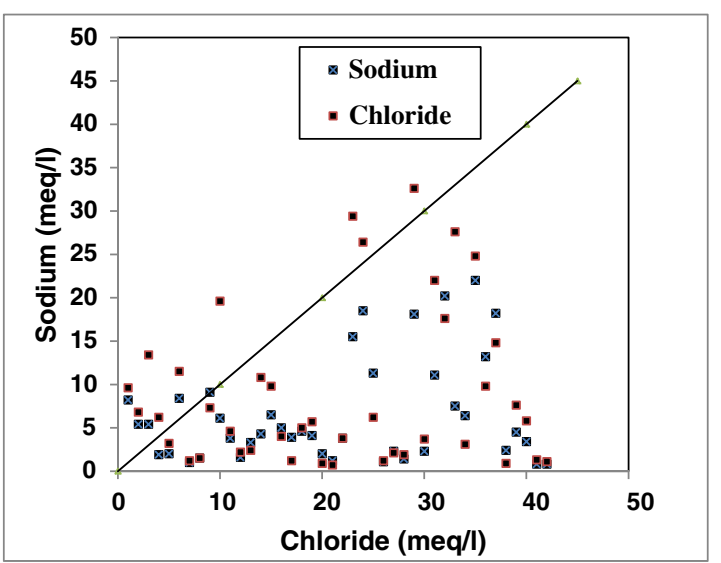

(b)
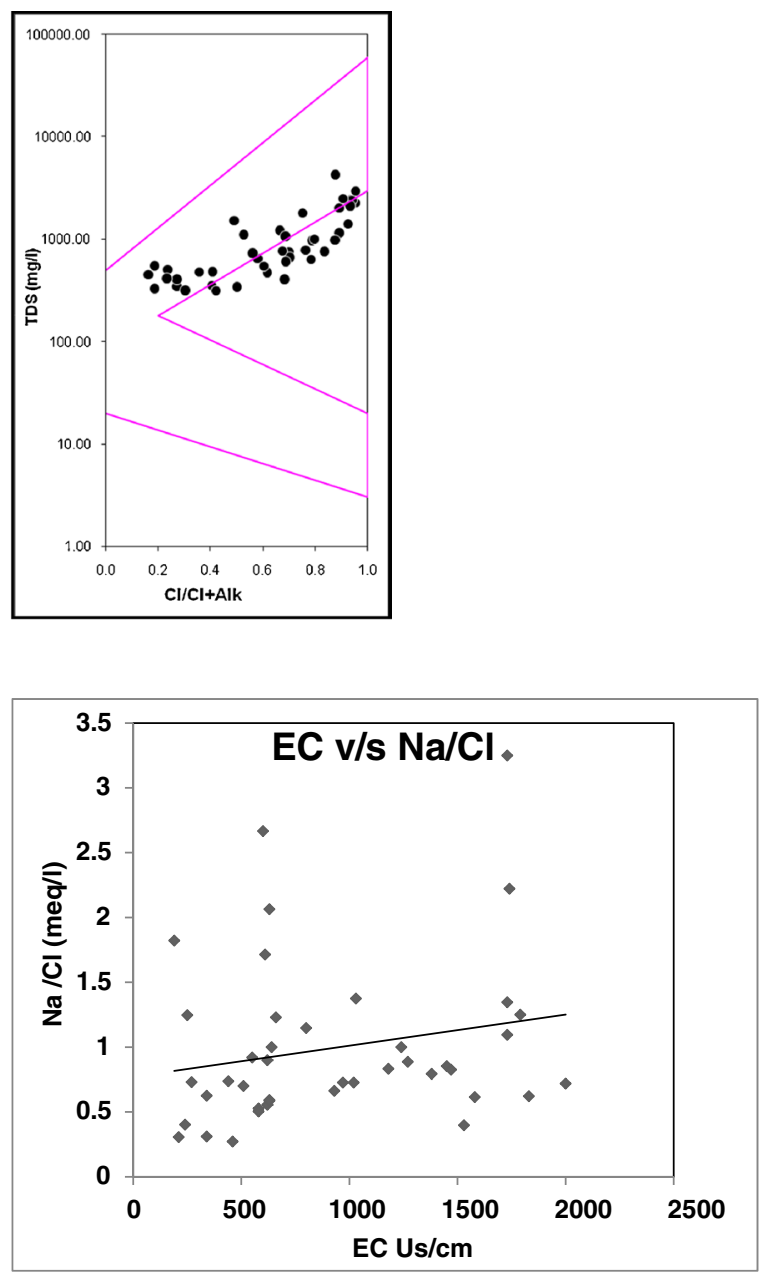

(c)

Figure 6. (a) Gibbs plot, (b) sodium vs. chloride plot and (c) electrical conductivity vs. sodium-chloride plot. 
of them in the evaporation zone, which indicates that interaction between aquifer materials and water is the major process controlling the groundwater chemistry of this area. Perusal of the figure shows that evaporation is not a dominant process in the study area. This is again reconfirmed from the plot between sodium to chloride ratio and from sodium to chloride ratio vs. EC (figure $6 \mathrm{~b}$ and $\mathrm{c}$ ). Concentration by evaporation process assuming that no mineral species are precipitated, would leave the ratio of sodium/chloride unchanged. Another plot of the sodium/chloride ratio vs. EC would therefore produce a horizontal line. The groundwater samples of the study area show variation in the sodium/chloride ratio (figure $6 \mathrm{~b}$ ). Sodium/chloride ratio vs. EC (figure 6c) of the study area produces a slightly inclined relationship, which indicates that evaporation is not a dominant process in the study area.

\section{Results and discussion}

\subsection{Structural control on groundwater}

Three lineaments/dykes were selected and groundwater conditions in the downstream and upstream of the lineament/dyke were studied in detail. Figure 7 shows the spatial distribution of the lineament/dyke.

- Almost west-east oriented lineament/dyke near village Valasai and surrounds have very good potential and potable quality. Lineament mapped is represented in figure as lineament-I (figure 7). About 200-250 m north and south of the lineament has areas with high potential groundwater sources. Details of these well areas are given in table 3 . A few wells in the vicinity of the village Kambanaeri falling in this zone have good discharge of 4-5 lps and can operate for 8-10 hrs with 1-1.5 m drawdown. Further, a few single wells in this zone irrigate up to 10 acres of land. The groundwater quality is highly fresh. Electrical conductivity values range from 800 to $1000 \mu \mathrm{S} / \mathrm{cm}$. Here the lineament acts as carrier and transmits fresh potable water directly from the recharge area, i.e., the bazada zone/foothills of the Western Ghats. $300 \mathrm{~m}$ on either direction, i.e., north and south of the lineament, the scenario changes very drastically. The quality of groundwater changes, electrical conductivity value changes from less than $1000 \mu \mathrm{S} / \mathrm{cm}$ in the vicinity of the lineament area to $1000-1800 \mu \mathrm{S} / \mathrm{cm}$. Yield of the wells outside the 200-250 $\mathrm{m}$ vicinity is very low. They yield groundwater in the range of $2-3 \mathrm{lps}$ with only 1-2 hours of pumping and drawdown created is in the range of 4-6 m, maximum available depth.

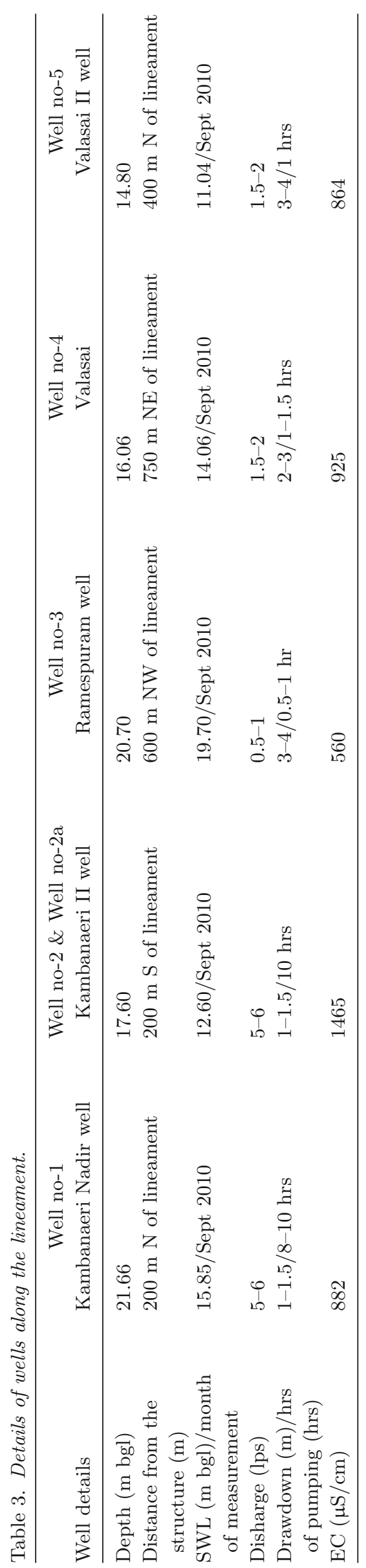


Recharge area of the study area is from the bazada zone/colluvial zones of the Western Ghats. Catchment of many west-east oriented lineamnets/ dykes is from these colluvial deposits. Recharge structures like the percolation pond/tank can be constructed in the bazada zone, so that the $\mathrm{W}-\mathrm{E}$ oriented dykes acting as conduit transmits more water to the downstream side and area of influence of beneficiary increases.

- North-south $\left(\mathrm{N} 40^{\circ} \mathrm{W}\right)$ oriented dyke near village Andarkulam (east of Sendamaran) have quality problems in the upstream side. Dyke/lineament is represented in the previous figure, labelled as II (figure 7). EC value ranges from 3000 to $4000 \mu \mathrm{S} / \mathrm{cm}$, while wells in the downstream side have EC ranging from $1300-1600 \mu \mathrm{S} / \mathrm{cm}$. The groundwater flow direction in the study area is from western/ northwestern towards the eastern/south-eastern direction. The dyke here acts as a barrier thereby hindering the normal groundwater flow in the study area. This barrier action of the dyke causes groundwater to stagnate for a longer period of time, which results in changes in groundwater quality. Rock-water interaction is a primary process that could result with increase in residence time, which is evident from the EC values on the upstream as well as the downstream side. Details of the wells falling in the upstream and downstream of the dyke are tabulated in table 4 . The downstream side has very low discharge and EC values change drastically. The discharges in the wells on the downstream side are very low. Wells yield 1.5-2 lps for 30-60 mins/day only.

- North-south $\left(\mathrm{N} 20^{\circ} \mathrm{E}\right)$ oriented dyke near village Marudappapuram have quality problems in the upstream side. The location of the dyke is represented in figure 7 . EC value ranges from 3700 to $4600 \mu \mathrm{S} / \mathrm{cm}$. Yield of these wells ranges from less than 2 to 3.5 lps. The wells located in the upstream side can run for 2-3 hours and they get dried. While in the downstream side of the dyke, the groundwater quality is drastically different. EC values are lower and range from 1800 to $2200 \mu \mathrm{S} / \mathrm{cm}$, but the yield is very poor, ranging from 1 to 2 lps and wells sustain for less than an hour only. Details of the wells in the upstream and downstream sides of the Marudappapuram dyke are tabulated in table 5 . The dyke cuts across the Chittar River near the village Arunachalapura-Nettur. The groundwater near the vicinity of the river is potable. The EC value ranges from 1000 to $1200 \mu \mathrm{S} / \mathrm{cm}$. The dyke near the river Chittar acts as a carrier to the vicinity of about 1 to $1.5 \mathrm{~km}$

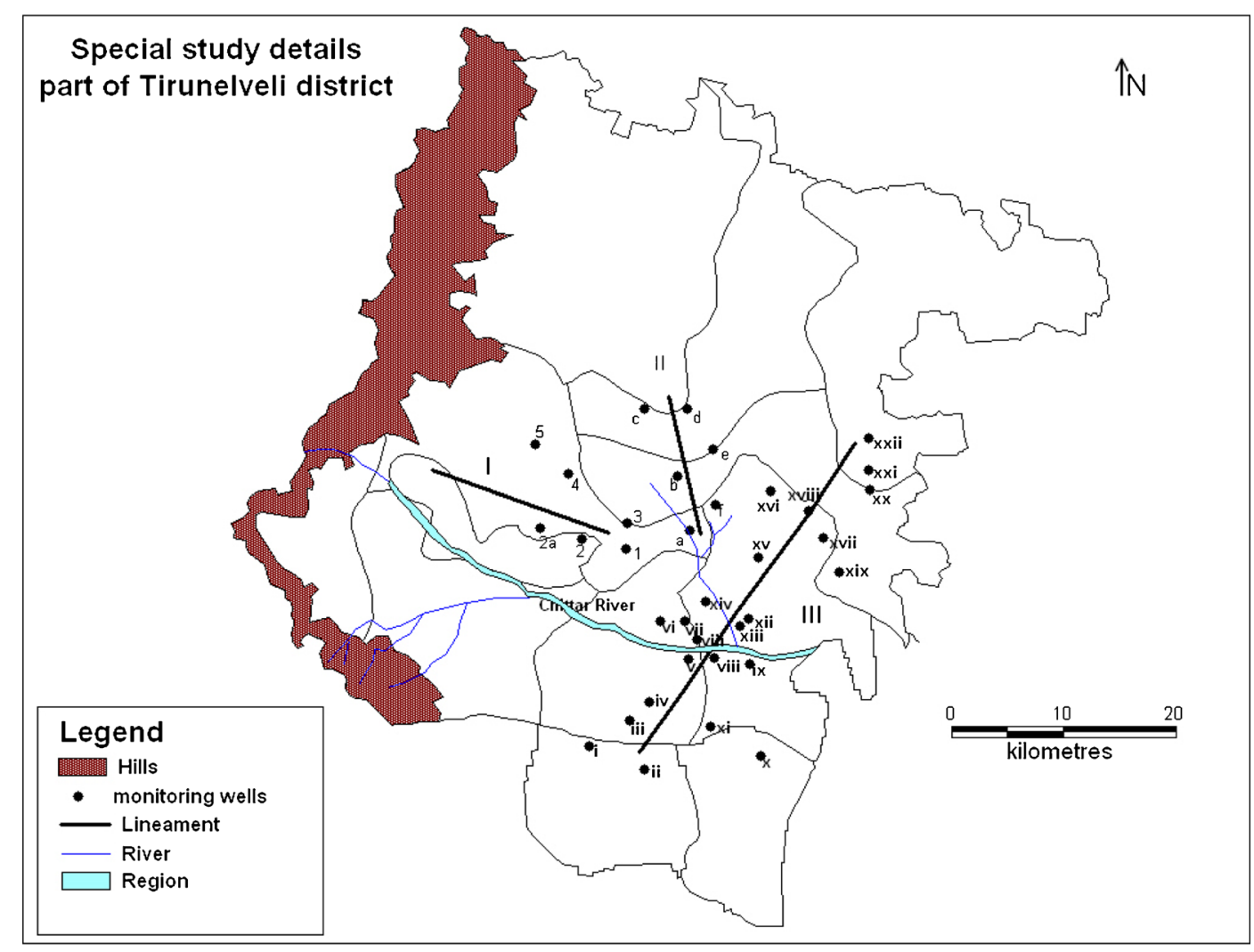

Figure 7. Map showing three lineaments. 


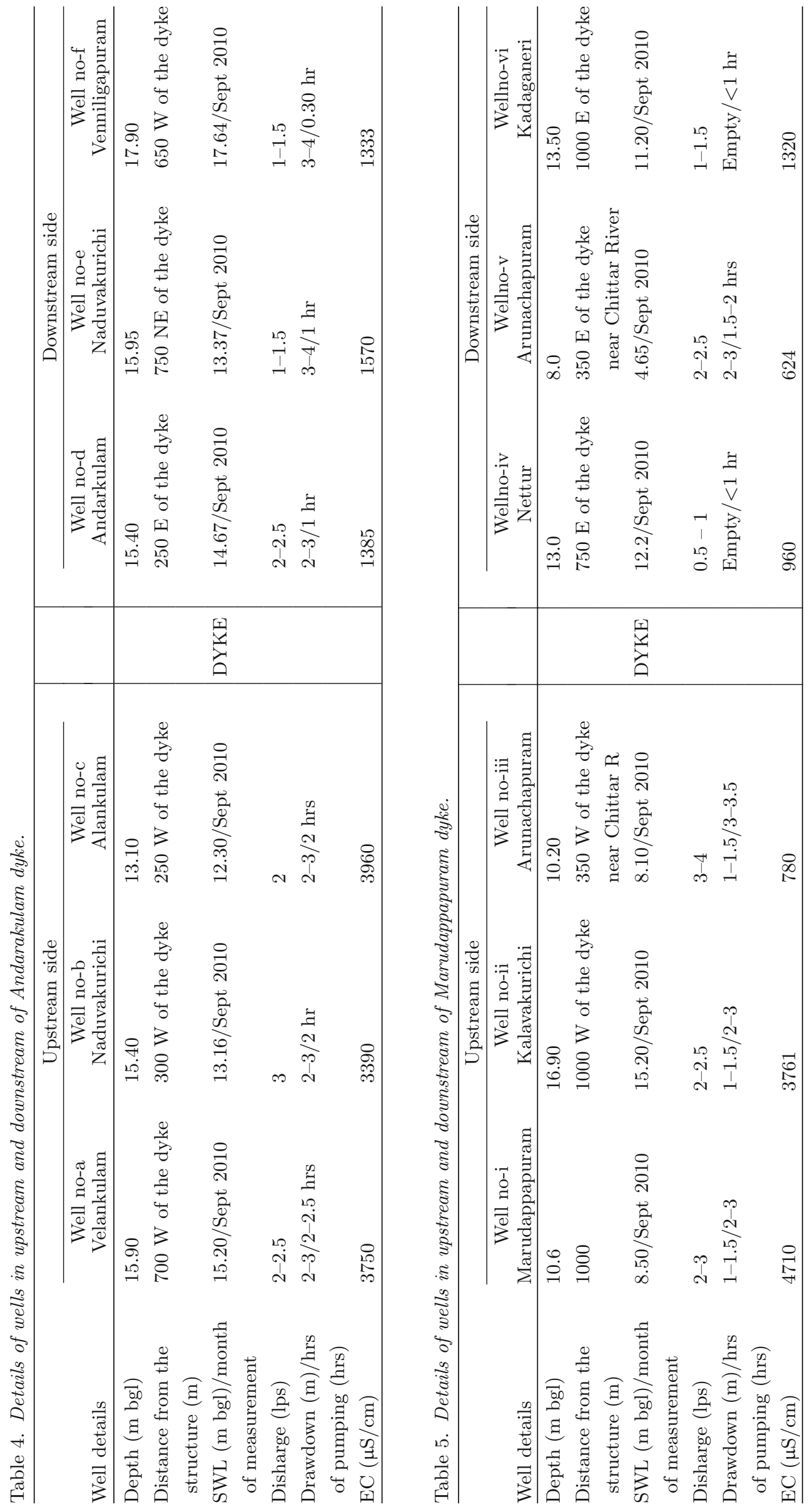


on both the sides. The wells in the downstream side have very low yield.

The same trend is observed in many key wells located in the upstream and downstream of the Marudappapuram dyke. Eight key wells located in the upstream side of Marudappapuram dyke and seven key wells monitored on the downstream side of the Marudappapuram dyke show quality and quantity variation. Wells in the upstream side have high EC with good to moderate discharge while the wells in the downstream side have very poor discharge with potable groundwater.

It is evident that the $\mathrm{W}-\mathrm{E}$ oriented lineament/ dyke is highly potential. The dyke/lineaments oriented in the $\mathrm{N}-\mathrm{W}$ and $\mathrm{NE}-\mathrm{SW}$ are associated with quality problems because these dykes stop the groundwater flow and cause stagnation of water, which finally results in problems in quality.

In order to increase the groundwater potential in the downstream side, the dyke can be excavated up to $2 \mathrm{~m} \mathrm{bgl}$ in the Chittar river section. Backfilling can be done with sand and gravel to allow flow and baseflow in the river. A check dam can be constructed about 100-200 $\mathrm{m}$ in the downstream side, which will increase the recharge from that point.

\section{Conclusion}

Groundwater is widely used for irrigation and domestic water needs of the study area. Groundwater in the study area occurs in the weathered/ fractured/jointed charnockitic/gar.biotite gneissic rocks. Groundwater is developed mainly by dugwells and occurs under unconfined condition. The aquifers of the study area have yield ranging from $<1$ to $8 \mathrm{l} / \mathrm{sec}$. Electrical conductance of groundwater ranges from 193 to $4830 \mu \mathrm{S} / \mathrm{cm}$. Groundwater flow direction is from the west to east/south-east direction. The groundwater flow and its quality are fully controlled as observed in the study area. Dykes and lineaments of the study area are of two types N-S and $\mathrm{W}-\mathrm{E}$ oriented structures. The $\mathrm{N}-\mathrm{S}$ oriented structures behave like a barrier while the W-E oriented structure acts as a carrier. These structures carry groundwater like a conduit from the recharge area, i.e., Western Ghats to the discharge area. An east-west lineament near Valasai having yield ranging from 5-6 lps can operate for $8-10$ hours with $1-1.5 \mathrm{~m}$ drawdown. The area beneficial is only $200 \mathrm{~m}$ north-south of the lineament. Groundwater can be lowered in this region during summer by pumping and groundwater level can be lowered to additional $7-8 \mathrm{~m}$, which will induce recharge subsequently during the rainfall.
Further, with construction of artificial recharge structures like percolation ponds in these bazada zones, which are the recharge areas for these $\mathrm{W}-\mathrm{E}$ oriented lineaments, the beneficial area can be increased. North-south oriented dykes $\mathrm{N} 40^{\circ} \mathrm{W}$ Ankarkulam and $\mathrm{N} 20^{\circ} \mathrm{E}$ Marudappapuram show quantity and quality variation on the upstream and downstream side. The discharge decreases and EC value lowers on the downstream side, while on the upstream side, high EC and moderate to high discharge is observed. Groundwater flow direction is from the west to the east/south direction. Since these dykes are cutting across the groundwater flow the EC values increase due to stagnation. Increase in residence time and rock-water interaction lead to deterioration of groundwater quality. Thus the geologic structures play a major role in groundwater flow and quality in the study area.

\section{Acknowledgements}

Authors wish to thank the Chairman, CGWB, New Delhi for his permission to publish the research work. Thanks are also extended to Member, WQ \& TT, Faridabad. The first author expresses his special thanks to Dr S Suresh, Sh V Dhinagaran, Dr K Ravichandran, and Sh N Rameshkumar, for the support and help rendered during the study.

\section{References}

Al-Taj M 2008 Structural control on groundwater distribution and flow in Irbid area, North Jordan; Jordan J. Earth Environ. Sci. 1(2) 81-88.

Gibbs R J 1970 Mechanisms controlling world's water chemistry; Science 170 1088-1090.

ISI (Indian Standards Institution) 1983 Indian Standard specification for drinking water, IS 10500.

Kunhambu V 1990 CGWB technical series report: Systematic hydrogeological surveys in parts of TirunelveliKattabomman district; 52p.

Mondal S, Md Pandey A C and Garg R D 2007 Groundwater prospects evaluation based on hydrogeomorphological mapping using high resolution satellite images: A case study in Uttarakhand; J. Indian Soc. Remote Sens. 36 69-76.

Nag S K 2005 Application of lineament density and hydrogeomorphology to delineate groundwater potential zones of Baghmundi block in Purulia district, West Bengal; J. Indian. Soc. Remote Sens. 33(4) 521-529.

Nilsen K H, Sydnes M, Gudmundsson A and Larsen B T 2003 How dykes affect groundwater transport in the northern part of the Oslo Graben, EGS-AGU-EUG Joint assembly, Abstracts from the meeting held in Nice, France, pp. 6-11.

Perrin J, Ahmed S and Hunkeler D 2011 The effects of geological heterogeneities and piezometric fluctuations on groundwater flow and chemistry in a hard-rock aquifer, southern India; Hydrogeol. J., doi: 10.1007/s10040-011-0745-y. 
Ramsahoy L E and Delang S M 1961 A simple method for determining specific yield from pumping test, U.S. Geological Survey Water Supply. Paper $1536 \mathrm{C}$.

Sampath Kumar E 1994 CGWB technical series report: Reappraisal: hydrogeological surveys in parts of Tambraparni and Nambiyar river basins in Tirunelveli and V.O. Chidambaranar district, 91p.

Senthilkumar M 2010 CGWB technical series report. Groundwater Management Studies: Identification of artificial recharge sites in water scarce areas in northern part of Tirunelveli district, southern India, 88p.
Srinivasa R Y and Jugran K D 2003 Delineation of groundwater potential zones and zones of groundwater quality suitable for domestic purposes using remote sensing and GIS; Hydrogeol. Sci. J. 48 821-833.

Vardaraj N 1984 CGWB technical series report: G.W resources and development potential of TirunelveliKattabomman district, 65p.

Vasanthavigar M, Srinivasamoorthy K, Vijayaragavan K, Gopinath S and Sarma S 2011 Groundwater potential zoning in Thirumanimuttar sub-basin Tamil Nadu, India - A GIS and remote sensing approach; Geo-spatial Infor. Sci. 14(1) 17-26. 